\title{
耐食性を高めた亜鉛系表面処理鋼板の開発動向
}

\author{
高 橋彰* \\ *新日本製鉄(侏) 君津技術研究部(干299-1141 千葉県君津市君津 1)
}

\section{Improvement in the Corrosion Protection of Galvanized Steel Sheets}

\author{
Akira TAKAHASHI*
}

*Kimitsu R\&D Lab., Nippon Steel Corporation (1, Kimitsu, Kimitsu-shi, Chiba 299-1141)

Keywords : Zn, Corrosion, Mg, Galvanized Steel Sheet

\section{1.はじめに}

亜鉛めっき鋼板は，以前は「トタン板」と呼ばれていたが， これはポルトガル語で「亜鉛」を表す「tutanaga =トタナ ガ」が変化したものとも言われている11。亜鉛めっきは鉄に 対する犠牲防食作用と安定な白錆によるバリア作用とにより 優れた耐食性を示し, 鉄の欠点である腐食を抑制する。わが 国の亜鉛めつき鋼板の歴史は古く, 1906 年に官営八幡製鉄 所でフラックス法により作られた 40 トンが始まりである2)。 当時は, 切り板のドブ付けめっきであったが，その後，コイ ルによる連続めつき技術 (溶融めつき, 電気めつき)が開発さ れ生産量が大きく増大した。その結果, バケッ・たらい・衣 装缶・米びつや雨どいなどの日常生活に密着した工業製品に 広く使われるようになった。さらに, 高度成長期以降は, 自 動車車体や家電・電機製品などの耐久消費財にも大量に使わ れるようになり, 生産量は年間 1300 万トンを超え(2004 年) ${ }^{3)}$, 日本の工業製品を支える安価で高品質な素材として の重要な役割を果たしている。

現在，市場は亜鉛めっき鋼板に対して，1) 環境対応，2)要 求特性の多様化, 3) 他素材との競争力, を求めている。環境 対応とは, 環境負荷物質低減や長寿命化であり, クロメート フリー後処理, 高耐食性めっき, 塗装鋼板などが開発された。 また, 要求特性の多様化とは, 需要家の用途拡大に対応した もので, 屋根材やたらいが主用途だった時代の要求特性から は想像もできない種々の性能を発現するようになっている。 たとえば, 耐污染性4), 放熱性5), 深絞り加工性6)などの性能 を有する亜鉛めつき鋼板が開発された。さらに，他素材との 競合も厳しさを増しており, 樹脂, 軽金属との市場の鬩ぎ合 いの中, 鋼製部材の軽量化や高加工性による生産性の向上が 進行中だ。このような市場環境の中, 鉄鋼各社は品質改善, 新商品開発に努めており, めっき層の改質は勿論のこと, 化 成処理・塗装処理の高性能化に取り組んでいる。このように, 亜鉛めっき鋼板に求められる性能は, 複雑化・高度化してい るが, 基本となる性能は防錆性であり, 高防錆化の市場要求
は今なお強い。それに答えるべく研究開発は進んでおり，腐 食・防食の基盤研究と新めっき開発が一体となってお互いを 補完し合いながらなされてきている。

ここでは, 近年特に目覚しい進歩を遂げた, 主に建材用途 向けの高耐食性溶融亜鉛めつき鋼板の開発事例を紹介する。 この開発品は, これまでの亜鉛系めつき鋼板の防錆機構の知 見や腐食評価法に関する基盤的な研究に支えられて得られた ものと言ってもよく，これら基盤技術との連関性も触れなが ら概要を述べさせていただく。

\section{2. $1970-80$ 年代の車体用高防錆鋼板の開発}

\section{1 車体用防錆鋼板の開発経緯}

わが国の亜鉛系めっき鋼板の品質と製造技術は，1970 年 代後半から始まった車体用防錆鋼板の開発の過程で大きく進 展した。当時, 北米では, 冬季の路面凍結防止用の岩塩散布 により車体の腐食が社会問題化し，1978 年にカナダコード と呼ばれる具体的な防錆目標が定められた。これは, ドアへ ム部などの塗装が䞟り込まない部位の耐食性(孔あき腐食) と 外板塗装面の疵部の耐食性 (外観腐食) を対象としており，そ の後, 北欧規格 (1983 年), 米国 Big 3 自主規格(1984 年)を 経て順次高度化した。米国自主規格は，孔あき錆無き事 10 年, 外観錆無き事 5 年で, この防錆目標の達成には, 高耐食 性の亜鉛系めっき鋼板の適用が不可欠であった。図 1 に，わ が国の車体用防錆鋼板の変遷を示す7)。防錆鋼板は, 溶融系, 電気系, 塗装系の三種類に大別されるが, 国内自動車メー カーは最終的に合金化溶融亜鉛めっき鋼板 (GA 鋼板), 電気 覀鉛-ニッケルめつき鋼板, 薄膜有機塗装された電気亜鉛 ーニッケルめつき鋼板 (有機複合鋼板) を選択した。これらの めつき鋼板実用化の影で, 鉄鋼各社はより耐食性に優れた めつき鋼板の開発に取り組んでおり, $\mathrm{Zn}-\mathrm{Co}^{-} \mathrm{Cr}^{8)}, \mathrm{Zn}-\mathrm{Mn}^{9}$, $\mathrm{Zn}-\mathrm{Cr}^{10)}, \mathrm{Zn}-\mathrm{Co}-\mathrm{Cr}-\mathrm{Al}_{2} \mathrm{O}_{3}{ }^{11)}, \mathrm{Zn}-\mathrm{Ni}-\mathrm{SiO}_{2}{ }^{12)}, \mathrm{Zn}-\mathrm{Ni}$ $-\mathrm{BaCrO}_{3}{ }^{13)}$ などの電気めつき鋼板や $\mathrm{Zn}-\mathrm{Mg}^{14)}, \mathrm{Zn}-\mathrm{Ti}^{14)}$ どの蒸着めっき鋼板が検討された。また, 腐食・防食のメカ ニズムの解析も行われ, めつき鋼板の腐食挙動調査, 腐食環 


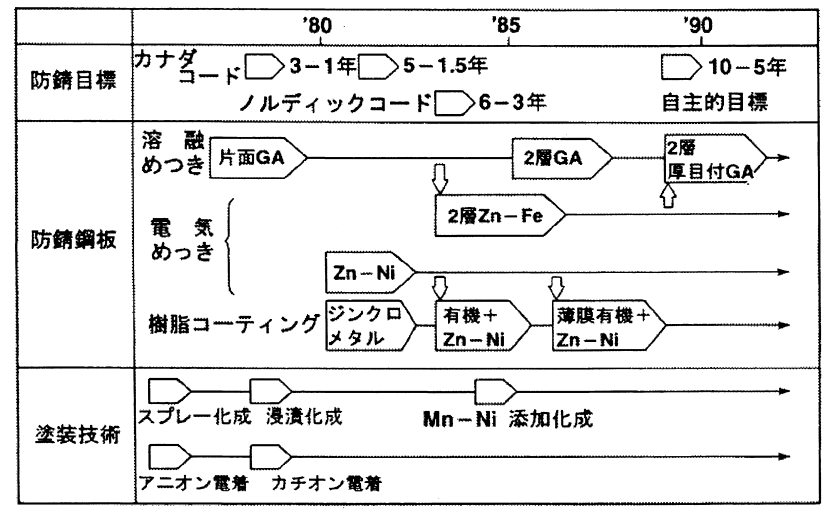

注） GA：合金北溶融Znめっき鋠板

図 1 わが国の車体用防錆鋼板の変遷7)

境のモニタリング，亜鉛めつきの防錆メカニズム解析，腐食 促進試験条件の確立がなされていった ${ }^{15)}$ 。図 2 に，腐食促進 試験条件の確立に関する結果の一例を示す ${ }^{16)}$ 。冷延鋼板，電 気亜鉛めっき鋼板，合金化溶融亜鉛めつき鋼板に車体用の塗 装処理を施し，湿潤比率の異なる腐食促進試験を行った際の カット疵部のふくれ幅を示したものである。湿潤率 $66 \%$ 以 上では，冷延鋼板よりもめつき鋼板の方がふくれ幅が大きい が，50\%で同程度となり，40\%前後では逆に冷延後半のふく れ幅が大きくなる。自動車の車体外面は，常に湿潤状態にあ るとは考えにくいので，湿潤率の高い塩水噴霧試験のような 試験は，実車環境を正しく再現しておらず，間違った材料を 選定してしまう危険性があることを明らかにした。

前述した多くの新めっき鋼板は，残念ながら実用化される ことなく終わった。しかし，開発の過程で得られたこれらの 知見から，耐食性を向上させるための方向性に関する知見が 得られ，また，新めっきの耐食性を正確に評価するための腐 食環境選定の重要性が認識されるようになり，直近の各種防 錆鋼板開発の礎になったといってよい。

\section{2 合金化による Zn めっきの耐食性向上}

亜鉛系めっき鋼板の耐食性は，亜鉛の鉄に対する犠牲防食 作用と白錆によるバリア作用とによって発現している。犠牲 防食作用は，亜鉛の溶解により発現することから耐食性の向 上にはめっき付着量の増大が確実かつ有効な方法となる。そ の一方で，白錆のバリア性が高まればめっき層の溶解速度が 抑制され，めっき付着量を増大させることなく長期間の犠牲 防食作用を期待できる。これまでの研究から，白錆のバリア 性は亜鉛の腐食生成物の形態と相関があり，塩基性塩化亜鉛 のバリア性が良好で酸化亜鉛のそれは不良であると考えられ ていた。そして，この塩基性塩化亜鉛の長期安定化に $\mathrm{Al}$, $\mathrm{Cr} ， \mathrm{Ni}, \mathrm{Co}$ などの添加合金が寄与することが擬似錆の実験

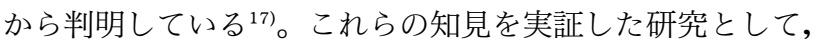
川福らは，蒸着めっきの手法を用いることで，電気めっきや 溶融めっきでは得られない合金系も含めた亜鉛合金めっき鋼 板の耐食性を評価した。図 3 に塩水噴霧試験 (SST) での赤 錆発生時間と二種類の腐食生成物の $\mathrm{X}$ 線回折強度比(塩基性 塩化亜鉛の (0003) 面と酸化亜鉛の (100) 面の強度比) との関係 を示す ${ }^{14)}$ 。比較材の電気純亜鉛めっき(EG) は付着量が $40 \mathrm{~g} /$ $\mathrm{m}^{2}$ と他の合金めっきの 2 倍であるにもかかわらず，50 時間

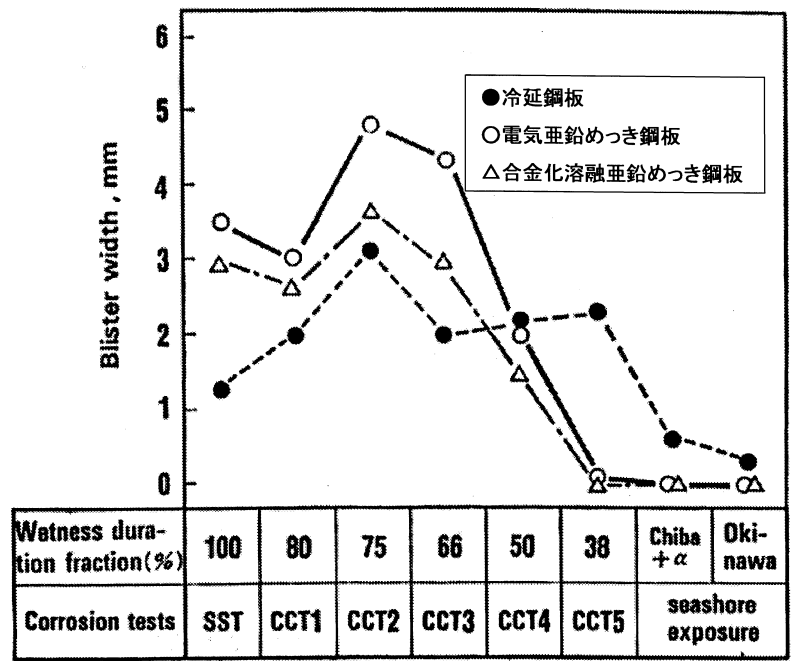

$\alpha:$ Sea-Water spray twice a week

図2 各種腐食条件 1 ケ月後の塗膜ふくれ幅の変化 ${ }^{16)}$

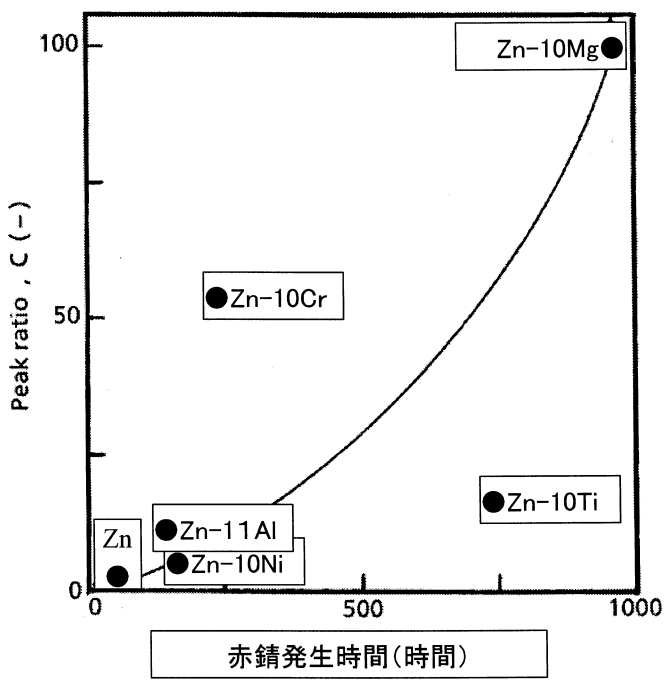

図 3 各種合金めっき鋼板の赤錆発生時間と腐食生成物の $\mathrm{X}$ 線回 折ピーク強度比との関係 ${ }^{14)}$

ほどで赤錆発生した。また，塩基性塩化亜鉛以外に酸化亜鉛 の回折強度も強く認められた。一方，合金化するといずれの めっきも耐食性が大きく向上することがわかる。最も耐食性 が良好なのは $\mathrm{Zn}-\mathrm{Mg}$ で赤錆発生時間は約 950 時間であった。 また, 塩基性塩化亜鉛のみの回折ピークが認められ, 回折強 度比は大きな值となった。ただし，全めっき種で見た場合， 耐食性と錆層の回折強度比との関係は良好な相関関係がある とはいえず，Zn-Ti のように耐食性が極めて良好であるに もかかわらず塩基性塩化亜鉛の比率が小さい例もあった。 Zn-Ti は，錆層のバリア性よりも Zn と Ti との合金相形成 によるめっき層自身の溶出速度の低下に起因していると推定 した。Ti は極めて強力な不働態化金属であることが影響し ていると考えられる。一方, 耐食性が良好で回折強度比が大 きい $\mathrm{Zn}-\mathrm{Mg}$ の錆層は，六方晶である塩基性塩化亜鉛の最も 稠密な面がめっき基盤と平行に配向しており，バリア性が強 く発揮されたと推定した。

以上の結果から，亜鉛めっきの耐食性を向上させる要因と して，錆層の安定化とめっき層の不活性化があることがわ 
かった。しかし，耐食性向上の方向性は見出せたものの， $\mathrm{Zn}-\mathrm{Mg}$ や Zn-Ti 合金系は, 既存のプロセスである電気・溶 融めっき系での製造は難しく，現在まで商業製品には至って いない。

\section{Mg を添加した溶融亜鉛めっき鋼板の開発}

\section{1 溶融 $\mathbf{Z n}-0.5 \% \mathrm{Mg}-0.2 \% \mathrm{Al}$ 合金めつき鋼板 ${ }^{18) ~ 20) ~}$}

溶融亜鉛めつき鋼板は，安価で優れた耐食性を有すること から土木・建築分野で広く使われている。耐食性の要求度に 応じてめっき付着量は選択され，片面あたり 90〜 $300 \mathrm{~g} / \mathrm{m}^{2}$ が使い分けられている。しかし，腐食環境の厳しい海岸周辺 のいわゆる塩害地域では，亜鉛めっき鋼板の腐食速度は $20 \sim 30 \mathrm{~g} / \mathrm{m}^{2} /$ year と大きく, 厚目付け化による対応では限 界があり，高耐食性めっきの開発が求められていた。これま でに，溶融亜鉛や電気亜鉛めっきに微量の $\mathrm{Mg}$ を添加する ことにより，塩水噴霧試験での耐食性が大きく向上すること が知られていた。図 4 は, $\mathrm{Mg}$ 含有量と塩水噴霧試験での腐 食速度との関係を示したもので， $\mathrm{Mg}$ を添加することで腐食 速度は約 7 分の 1 に減少することがわかる ${ }^{18)}$ 。新頭らは，こ の耐食性や操業性，経済性を考慮して溶融 Zn-0.5\% Mg $-0.2 \% \mathrm{Al}$ 合金めっき鋼板を開発した。得られためっき層は, 亜鉛結晶粒の粒界に $\mathrm{MgZn}_{2}$ もしくは $\mathrm{Mg}_{2} \mathrm{Zn}_{11}$ の金属間化 合物が析出した構造になっている。大気促進試験 ( $5 \% \mathrm{NaCl}$ 散布：2 回／週）による腐食減量は，図 5 に示すとおり溶融 亜鉛めっき鋼板の 3 割程度にまで減少しており，耐食性の向 上が確認された。大気促進試験 10 力月後の腐食生成物の $\mathrm{X}$

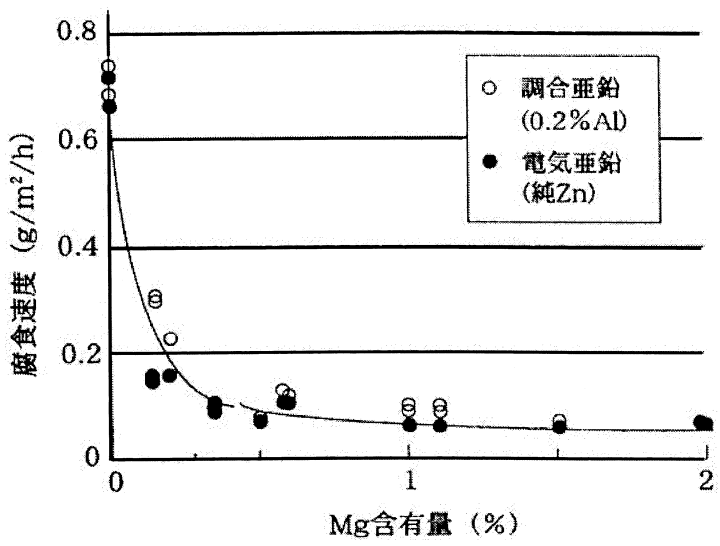

図 4 溶融亜鉛めつき中の $\mathrm{Mg}$ 含有量と腐食速度との関係 ${ }^{18}$

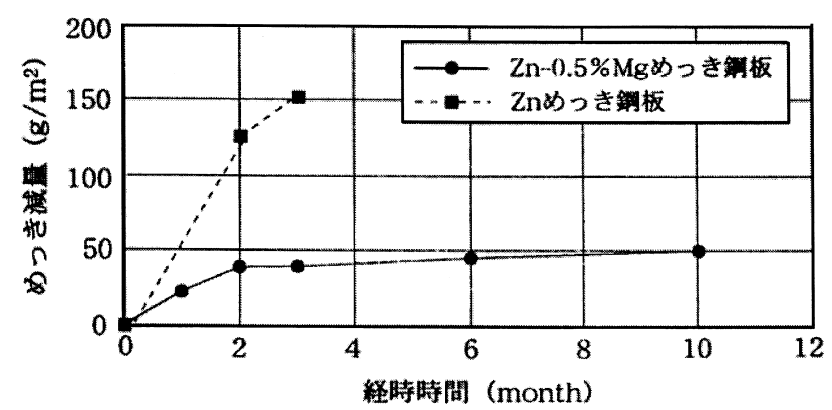

図 5 大気促進試験における $\mathrm{Zn}-0.5 \% \mathrm{Mg}-0.2 \% \mathrm{Al}$ めっきの耐 食性 ${ }^{18)}$

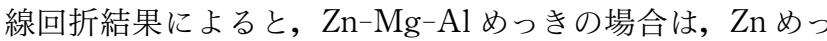
きと比較して Zn 腐食生成物のピーク強度が高く, 腐食生成 物がより多く残存していた ${ }^{18)}$ 。さらに， $\mathrm{Zn}-\mathrm{Mg}-\mathrm{Al}$ めっき の腐食生成物は塩基性塩化亜鉛の割合が大きかった。した がって, $\mathrm{Zn}-\mathrm{Mg}-\mathrm{Al}$ めっき鋼板は $\mathrm{Mg}$ の作用により塩基性 塩化亜鉛が長時間安定化されることで耐食性の向上が発現し たと考えられる。

3. 2 溶融 $\mathbf{Z n}-6 \sim 11 \% \mathbf{A l}-3 \% \mathbf{M g}$ 合金めっき鋼板 ${ }^{21) 28)}$

$\mathrm{Mg}$ は, 微量の添加であるにもかかわらず耐食性向上効果 が大きいことが示された。しかし, 耐食性の更なる向上に対 する要求は強く, $\mathrm{Mg}$ をさらに多量に添加した溶融亜鉛めっ き鋼板が検討された。しかし，溶融亜鉛めっき浴に $\mathrm{Mg}$ を 多量に添加すると, $\mathrm{Mg}$ は酸素との親和力が強いために大気 と接するめっき浴表面で $\mathrm{Mg}$ の酸化物が生成しめつき層中 に巻き込まれて品質を落としてしまう。ところが，浴中に $\mathrm{Al}$ を複合添加すると $\mathrm{Mg}$ の酸化物生成を抑制できることを 見出した ${ }^{26)}$ 。このようにして開発された新めつきの一つは, 森本らの溶融 $\mathrm{Zn}-11 \% \mathrm{Al}-3 \% \mathrm{Mg}-0.2 \% \mathrm{Si}$ 合金めつき21) 24) で，他方は清水らの溶融 $\mathrm{Zn}-6 \% \mathrm{Al}-3 \% \mathrm{Mg}$ 合金めつ き25) 26) である。両者のめっきは $\mathrm{Al}$ を多量に含有する点と $\mathrm{Mg}$ を 3 \%含有する点で共通しており, どちらも大幅な耐食 性の向上が認められた。図 6 は, $\mathrm{Zn}-11 \% \mathrm{Al}$ 合金系での $\mathrm{Mg}$ の添加量と塩水噴霧試験 500 時間後の腐食減量との関係を示 したもので, $\mathrm{Mg}$ の添加により腐食減量が 3 分の 1 にまで減 少している ${ }^{21)}$ 。同様の結果は，清水らの合金系でも得られて おり，複合環境サイクル試験 (JASO-M 609-91)で $6 \% \mathrm{Al}$ $-3 \% \mathrm{Mg}$ 合金は $0.2 \% \mathrm{Al}$ 合金(一般の亜鉛めつき)の実に 10 倍以上の耐食性を示した ${ }^{26)}$ 。また, 図 7 は, Zn-11\%Al $-3 \% \mathrm{Mg}-0.2 \% \mathrm{Si}$ 合金系の塩水噴霧試験 24 時間後の腐食生 成物層の SEM を示したもので, $\mathrm{Mg}$ の添加や $\mathrm{Si}$ の複合添加 で腐食生成物が微細な形状になりち密化していることがわか $3^{22)}$ 。沖縄暴露試験 1.5 年後の腐食生成物の $\mathrm{X}$ 線回折評価 においても $3 \% \mathrm{Mg}$ 含有めっきは, $\mathrm{ZnO}$ の生成が認められず, 塩基性塩化覀鉛や塩基性炭酸覀鉛のみからなっていた ${ }^{22)}$ 。同 様に清水らは沖縄暴露 5 年後の溶融 $\mathrm{Zn}-6 \% \mathrm{Al}-3 \% \mathrm{Mg}$ 合 金めつきの腐食生成物の構造を X 線回折と TEM 観察で明

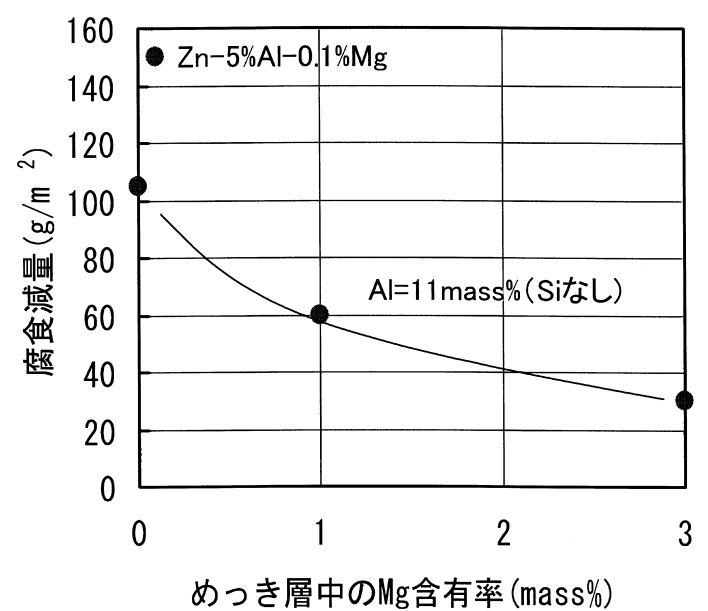

図 6 塩水噴霧試験 500 時間後の腐食減量に対するめつき層中の $\mathrm{Mg}$ の影響21) 


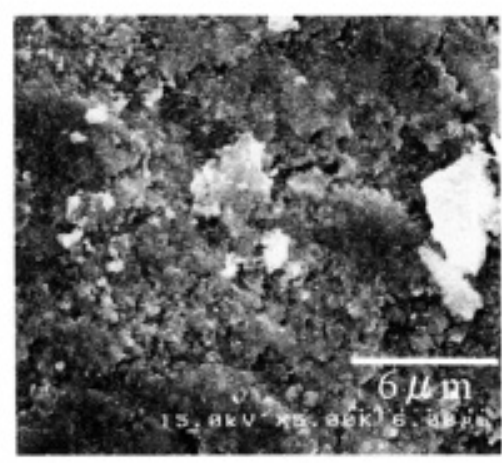

A

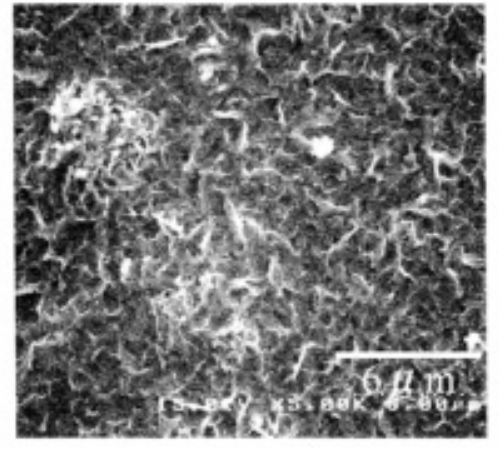

B

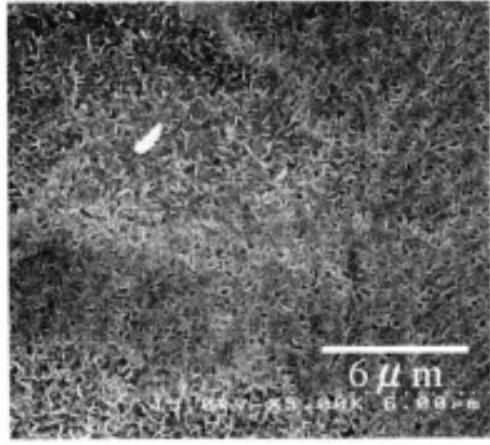

C

図 7 塩水噴霧試験 24 時間後の表面腐食生成物の SEM 像 ${ }^{22}$

$\mathrm{A}: \mathrm{Zn}-5 \% \mathrm{Al}-0.1 \% \mathrm{Mg}, \mathrm{B}: \mathrm{Zn}-11 \% \mathrm{Al}-3 \% \mathrm{Mg}, \mathrm{C}: \mathrm{Zn}-11 \% \mathrm{Al}-3 \% \mathrm{Mg}-0.2 \% \mathrm{Si}$

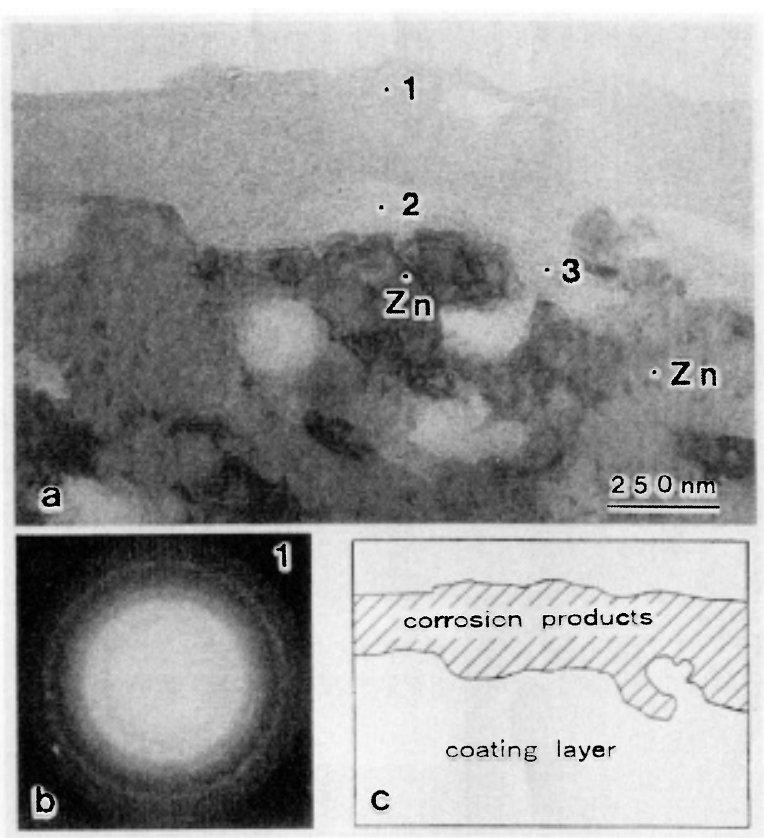

図 85 年間暴露した $\mathrm{Zn}-6 \% \mathrm{Al}-3 \% \mathrm{Mg}$ めっき鋼板の TEM 像と電子線回折 ${ }^{27)}$

$\mathrm{a}$ ：明視野像，b：1の部位の電子線回折像， $\mathrm{c}$ ：明視野 像の模式図

らかにした。その結果，腐食生成物層は塩基性炭酸亜鉛アル ミニウムと塩基性塩化覀鉛からなり，酸化亜鉛はほとんど生 成していないこと，この腐食生成物層は図８に示すように厚 みが約 $350 \mathrm{~nm}$ で $\mathrm{Mg}$ を含んだ非晶質物質と塩基性塩化物の 微細結晶とから構成されていることが示された ${ }^{27)}$ 。さらに, これらの鋼板の人工雨水 $\left(200 \mathrm{ppmCl}^{-}, 200 \mathrm{ppmSO}_{4}{ }^{2-}\right.$ 水溶 液) 中での分極測定を行ったところ，図 9 に示すように Zn - $6 \% \mathrm{Al}-3 \% \mathrm{Mg}$ 合金めっきは他のめっきと比べて溶存酸素 の還元反応の電位領域 $(-1.0$ から $-1.3 \mathrm{~V}$ vs. S.C.E.)の電 流密度が小さかった ${ }^{26)}$ 。したがって，塩基性塩化物を主体と するち密な腐食生成物が，腐食のカソード反応である溶存酸 素の還元反応を抑制することで耐食性が向上したことが明ら かになった。以上の結果から，両者の合金めっきは，図 $3 て ゙$ 示した蒸着めっき法による各種亜鉛合金めっきの結果と同様 に, $\mathrm{Al}$ と $\mathrm{Mg}$ が塩基性塩化物の形成と安定化に作用して優 れた耐食性を発現したものと結論できる。

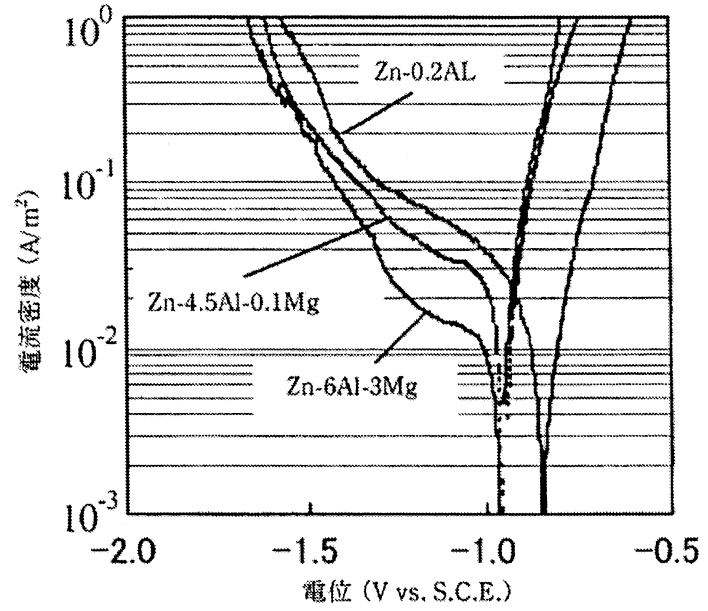

図 9 沖縄で 5 年間暴露した各種めっき銅板の分極曲線 26$)$ S.C.E：飽和カロメル電極

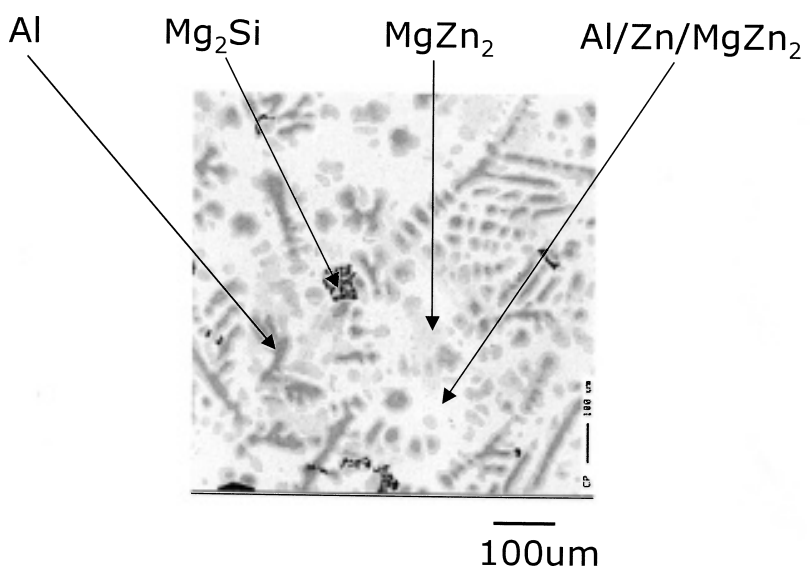

図 $10 \mathrm{Zn}-11 \% \mathrm{Al}-3 \% \mathrm{Mg}-0.2 \% \mathrm{Si}$ 合金の SEM 像 ${ }^{24)}$

このような耐食性を発現するめつき層の構造を図 10 に示 す24)。図 10 は, $\mathrm{Zn}-11 \% \mathrm{Al}-3 \% \mathrm{Mg}-0.2 \% \mathrm{Si}$ 合金を溶製法 で作製し，その組織をSEM で観察したものである。合金層 は, $\mathrm{Zn} / \mathrm{Al} / \mathrm{Mg}_{2} \mathrm{Zn}_{11}$ の三元共晶相をマトリックスとし て $\mathrm{Al}$ 相, $\mathrm{Mg}_{2} \mathrm{Si}$ 相, $\mathrm{Mg}_{2} \mathrm{Zn}_{11}$ 相が析出した構造からなる。 初晶の $\mathrm{Al}$ 相は, 樹脂状結晶の形態を有し, さらに個々の相 は $\mathrm{Zn}$ が共析した微細なラメラ組織になっている。 $\mathrm{Mg}$ を含 
有する $\mathrm{MgZn}_{2}$ 相は, $\mathrm{Al}$ 相に隣接して析出し, 三元共晶相は, 最後に凝固する相で合金層中に広く分布する。この合金の表 面を研磨し, 塩水噴霧試験で 1 時間腐食させ，直ちに EPMA で研磨面の酸素分布の状態解析を行ったところ, 酸 素の含有率は, Zn 含有率の高い相ほど大きいことがわかっ た。酸素は, 腐食生成物に起因することから, アノード反応 (溶解反応) は, 亜鉛含有率の高い相である $\mathrm{MgZn}_{2}$ 相や $\mathrm{Zn}$ $/ \mathrm{Al} / \mathrm{Mg}_{2} \mathrm{Zn}_{11}$ の三元共晶相で優先的に生じている。これ らの $\mathrm{Zn}$ 含有率が大きな相は, $\mathrm{Mg}$ も同時に含有することか ら腐食生成物への $\mathrm{Mg}$ の供給が生じやすく, 耐食性の向上 に繋がったと推定される。

\section{4. 将来展望}

以上，耐食性を高めた亜鉛系表面処理鋼板の開発事例とし て, Mg を含有する溶融亜鉛めっき鋼板について述べた。こ の新しいめっき鋼板は, 耐食性向上に寄与する合金添加効果 に関する過去からの設計指針が基礎となり，その添加を可能 とするプロセス技術を見出したことで実用化に至ったといえ る。これまで溶融めっき鋼板の分野では, 日本発の新しい合 金系の実用化は久しくなかったが, このめっき鋼板は, 平面 部, 加工部, 切断端面部のそれぞれにおいて優れた耐食性を 発現し, 塗装性・加工性・溶接性などに優れることから, 裸 仕様用途や後塗装用途, さらには塗装鋼板原板として, 今後 広い分野で使われることが期待されている。一方, 欧州の鉄 鋼メーカーは, 既存プロセスで亜鉛めっきを施した後に真空 蒸着ラインで $\mathrm{Mg}$ をめっきし，この二層めつきを熱処理す ることで $\mathrm{Zn}-\mathrm{Mg}$ 合金めっきを得る技術の開発を進めてい る ${ }^{29)}$ 。蒸着 $\mathrm{Zn}-\mathrm{Mg}$ めつきは，前述したようにわが国ではす でに検討済の技術ともいえるが，そこに敢えて挑戦してくる 彼らの熱意と今後の動向には注目したい。

今後もめっき層の更なる改善は続くと考えられるが, はじ めに述べたように需要家の要求性能がますます多様化し, 二 者背反的な性能の発現を要求する場合も多く, その実現が技 術的にどんどん困難になっていくと予想している。この要求 に対して, 基本的には化成処理や塗装処理といった後処理層 によって性能を担保するわけだが，たとえば，めっき層が後 処理層の性能の発現を助けたり, 後処理層が苦手な性能の一 部をめっき層が担保したりするといった発想をめっきの開発 に取り入れることが重要になってくると考えている。

持続可能な社会の実現が人類共通の課題になっているが, ここで述べてきた耐食性を高めた亜鉛めっき鋼板が, 鉄が持 つ高いリサイクル性, 腐食速度を低減したことによる長寿命 化，さらには環境負荷物質フリー(クロメートフリーの場合) といった長所を発揮することで貢献することを期待している。

(2005-9-30 受理)

\section{文献}

1）見坊豪紀, 金田一京介, 金田一春彦, 柴田 武 ; 大きい活字の 三省堂国語辞典, p. 773 (三省堂, 1986)

2 ）久松敬弘；金属表面技術, 34, 354（1983）

3 ）(社) 日本鉄鋼連盟編；鉄鋼需要統計月報, 490, 10 (2005)

4 ) 岡井敏博; 色材協会・関東支部講演会資料「機能性材料とそ
の技術」, p. 9 （色材協会, 1998）

5 ）平野康雄, 渡瀬岳史, 満田正彦 ; 表面技術, 53, 334 (2003)

6 ) 勝見俊之, 宮内優二郎, 斉藤勝士, 菊池郁夫, 圓山勝俊 ; まてり あ, 34, 789 (1995)

7 ) T. Hada ; Proc. Int. Conf. On Zinc and Zinc Alloy Coated Steel Sheet (GALVATECH' 89), p. 111 (Iron Steel Inst. Japan, 1989)

8 ) 松藤和雄, 安谷屋武志, 大村 勝, 樺沢 真, 庄司政浩 ; 日本鋼 管技報, 77, 103 (1978)

9 ) 杉本芳春, 浦川隆之, 鷺山 勝, 渡辺 勉; 材料とプロセス, 3 , 1535 (1990)

10) T. Kanamaru, S. Suzuki and K. Arai ; Proc. Int. Conf. On Zinc and Zinc Alloy Coated Steel Sheet (GALVATECH'92), p. 331 (1992)

11) S. Umino, C. Kato, T. Komori, A. Yasuda and K. Yamato ; Proc. Int. Conf. On Zinc and Zinc Alloy Coated Steel Sheet (GALVATECH' 89), p. 73 (Iron Steel Inst. Japan, 1989)

12）西村一実, 三吉康彦, 羽田隆司 ; 金属表面技術, 38, 217 (1987)

13）吉田 誠, 伊崎輝明, 大沢正巳, 樋口征順; 表面技術協会第 80 回講演大会要旨集, p. 267 (1989)

14）川福純司, 加藤 敦, 外山雅雄, 西本英敏, 池田貢基, 佐藤廣 志；鉄と鋼, 77, 995 (1991)

15）三吉康彦; 第 $138 ／ 139$ 回西山記念講座テキスト，141（日本 鉄鋼協会, 1991)

16）黒川重男, 番 典二, 大和康二, 市田敏郎 ; 鉄と鋼, 72, 223 (1986)

17）岡 襄二，朝野秀次郎，高杉政志，山本一雄；鉄と鋼，68, 82-A 57 (1982)

18）新頭英俊, 西村一実, 岡田哲也, 西村信明, 浅井謙一; 新日鉄技 報第 369 号, 61 (1998)

19）西村一実, 加藤憲治, 新頭英俊; 新日鉄技報第 371 号, 84 (1999)

20) K. Nishimura, H. Shindo, K. Kato, Y. Morimoto and S. Funaki ; Proc. Int. Conf. On Zinc and Zinc Alloy Coated Steel Sheet (GALVATECH' 98), p. 437 (Iron Steel Inst. Japan, 1998)

21）森本康秀, 本田和彦, 西村一実, 田中 暁, 高橋 彰, 新頭英俊, 黒崎将夫；新日鉄技報第 377 号, 22 (2002)

22）森本康秀, 黒崎将夫, 本田和彦, 西村一実, 田中 暁, 高橋 彰, 新頭英俊 ; 鉄と鋼, 89, 161 (2003)

23) S. Tanaka, K. Honda, A. Takahashi, Y. Morimoto, K. Nishimura and M. Sugiyama ; Proc. Int. Conf. On Zinc and Zinc Alloy Coated Steel Sheet (GALVATECH' 01), p. 153 (2001)

24）高橋 彰, 田中幸基, 林 俊一, 荘司浩雅 ; 材料とプロセス, 16, 1276（日本鉄鋼協会, 2003）

25）清水 剛, 吉崎布貴男, 三吉泰史, 安藤敦司 ; 日新製鋼技報, 85, 11 (2004)

26）安藤敦司; 金属, 74, 566 (2004)

27) 清水 剛, 吉崎布貴男, 三吉泰史, 安藤敦司; 鉄と鋼, 89, 166 (2003)

28) T. Tsujimura, A. Komatsu and A. Andoh ; Proc. Int. Conf. On Zinc and Zinc Alloy Coated Steel Sheet (GALVATECH' 01), p. 145 (2001)

29) C. Schwerdt, M. Riemer, S. Kohler, B. Schuhmacher, M. Steinhorst and A. Zwick; Proc. Int. Conf. On Zinc and Zinc Alloy Coated Steel Sheet (GALVATECH' 04), p. 783 (AIST, 2004) 